\title{
Yield Response of Drip-Irrigated Onion under Full and Deficit Irrigation with Saline Water in Arid Regions of Tunisia
}

\author{
K. Nagaz, ${ }^{1}$ M. M. Masmoudi, ${ }^{2}$ and N. Ben Mechlia ${ }^{2}$ \\ ${ }^{1}$ Laboratoire d'Aridoculture et Cultures Oasiennes, Institut des Régions Arides de Médenine, 4119 Médenine, Tunisia \\ ${ }^{2}$ Laboratoire de bioclimatologie, INAT, 43 Avenue Charles Nicolle, 2083 Tunis, Tunisia
}

Correspondence should be addressed to K. Nagaz, nagaz.kameleddine@ira.rnrt.tn

Received 11 April 2012; Accepted 8 May 2012

Academic Editors: C. Magill and L. Zeng

Copyright $\odot 2012$ K. Nagaz et al. This is an open access article distributed under the Creative Commons Attribution License, which permits unrestricted use, distribution, and reproduction in any medium, provided the original work is properly cited.

\begin{abstract}
A two-year study was conducted in arid region of Tunisia to evaluate the effects of deficit irrigation regimes with saline water on soil salinity, yield, and water use efficiency of onion grown in a commercial farm on a sandy soil and drip-irrigated with water having an $\mathrm{EC}_{i}$ of $3.6 \mathrm{dS} / \mathrm{m}$. Irrigation treatments consisted in water replacements of accumulated $\mathrm{ET}_{c}$ at levels of $100 \%$ (SWB100, full irrigation), $80 \%$ (DI-80), 60\% (DI-60), when the readily available water in the control treatment (SWB-100) is depleted, deficit irrigation during ripening stage (SWB100-MDI60) and farmer method corresponding to irrigation practices implemented by the local farmers. Results on onion production and soil salinization are globally coherent between the two-year experiments and show significant difference between irrigation regimes. Higher soil salinity was maintained in the root zone with DI-60 and farmer treatments than full irrigation (SWB-100). SWB100-MDI60 and DI-80 treatments resulted also in low EC $\mathrm{E}_{e}$ values. No significant differences were observed in bulbs fresh and dry yields, bulbs number $\cdot \mathrm{ha}^{-1}$ and weight from the comparison between full irrigation (SWB-100) and deficit treatments (DI-80, SWB100-MDI60). DI-60 irrigation treatment caused significant reductions in the four parameters considered in comparison with SWB-100. The farmer method caused significant reductions in yield components and resulted in increase of water usage 45 and 33\% in 2008 and 2009, respectively. Water use efficiency was found to vary significantly among treatments, where the highest and the lowest values were observed for DI-60 and farmer treatments, respectively. The full irrigation (SWB-100) and deficit irrigation (DI-80 and SWB100-MDI60) strategies were found to be a useful practice for scheduling onion irrigation with saline water under the arid Mediterranean conditions of southern Tunisia.
\end{abstract}

\section{Introduction}

Water scarcity is an increasingly important issue in many parts of the world. Climate change predictions of increase in temperature and decrease in rainfall mean water will become even scarcer. This is especially the case in arid regions of Tunisia subject to frequent droughts and where restricted supply of good quality water is the most important factor limiting crop production. Irrigation of a wide range of crops is expanding around shallow wells having a salinity ranging from 3 to $9 \mathrm{dS} / \mathrm{m}$. In the absence of sufficient rainfall events used elsewhere for natural leaching, irrigated farming in arid lands is exposed to accumulation of salts in the soils. Therefore, efficient use of saline water by irrigation is becoming increasingly important, and alternative water application method such as drip may contribute substantially to attain the twin objectives of higher productivity and optimum use of water. The trend in recent years has been towards conversion of surface to drip irrigation because cost of installation has relatively decreased with the easy access to subsidized drip irrigation equipment made possible recently. Drip irrigation, currently used in arid regions of Tunisia for high-value vegetable crop production such as onions, potatoes, peppers, and lettuces, can result in considerable saving in irrigation water, thus reducing the risks of salinization if the correct management procedures are applied.

Another way to address the issue of water shortage is through development of new irrigation scheduling techniques such as deficit irrigation, which are not necessarily based on full crop water requirement. Deficit irrigation provides a means of reducing water consumption while 
minimizing adverse effects on yield [1-8]. In this method, the crop is exposed to a certain level of water stress either during a particular period or throughout the whole growing season. The expectation is that any yield reduction (especially in water-limiting situations) will be compensated by increased production from the additional irrigated area with the water saved by deficit irrigation [9-11]. However, the grower must have prior knowledge of the crop yield responses to deficit irrigation. Many investigations have been carried out worldwide regarding the effects of deficit irrigation on yield of mainly horticultural crops [12-20]. Other experiments with onion [21] showed that deficit irrigation throughout the growing season of onion as 50 and $75 \%$ of $\mathrm{ET}_{c}$ reduced yields from full irrigation and resulted in the highest water saving and crop water use efficiency. Kumar et al. [22] investigated also the impact of deficit irrigation strategies on onion yield and water savings. They reported that applying 80 and $60 \%$ of crop water requirements resulted in yield decreases of 14 and $38 \%$ and saved 18 and $33 \%$ of irrigation water compared to full irrigation in 2 years, respectively.

Information is limited about deficit irrigation scheduling of onion especially under arid climate where onion, classified as a sensitive plant [23], is one of the important horticultural crops in arid regions of Tunisia. Productivity is usually low, and irrigation with waters having an ECi more than $3 \mathrm{dS} / \mathrm{m}$ is commonly practiced on a routine basis without scheduling and provision drainage, and it carries the danger of a rapid soil salinization because of increased salt input. Thus, there is a need to develop strategies based on irrigation restrictions during the whole growing period that may help to save water and control salinity under conditions of high evaporative demand and chronic shortages without substantially affecting yields. Therefore, various deficit irrigation strategies have been applied to onion crop. Considering this, the objective of the study was to make quantitative assessments of both salt accumulation in the soil and yield response to full and deficit irrigation strategies with saline water in order to derive an irrigation strategy that save water in drip-irrigated onion, reduce salt input, and improve water productivity under the arid Mediterranean conditions of southern Tunisia.

\section{Materials and Methods}

2.1. Experimental Site and Climate. The field experiment was carried out during the growing season of 2008 and 2009, between the months of March and August, in the southern east of Tunisia in a commercial farm situated in Médenine. The climate of the region is typical of arid conditions. The average temperature and $\mathrm{ET}_{o}$ rate during first year ranged from 11.2 to $33.1^{\circ} \mathrm{C}$ and 2.1 to $7.5 \mathrm{~mm}$, respectively, and in the second year, these parameters were varied, respectively, from 10.7 to $32.9^{\circ} \mathrm{C}$ and 2.2 to $7.2 \mathrm{~mm}$ during the crop growing season. Rainfall during crop growing season was recorded as 38 and $47 \mathrm{~mm}$ in the first and second years, respectively. The soil is of a sandy type with low organic matter content. The electrical conductivity $\left(\mathrm{EC}_{e}\right)$ values measured before planting were, respectively, 2.6 and $2.3 \mathrm{dS} / \mathrm{m}$ (0-60 cm depth of soil) for the first and second years.
The total soil available water calculated between field capacity and wilting point for an assumed onion root extracting depth of $0.60 \mathrm{~m}$ was $75 \mathrm{~mm}$.

\subsection{Crop Management and Experimental Design. Onion} seedlings (Allium cepa L.), light red local population, were transplanted on 10 March in each year with plant and row spacing of $0.2 \mathrm{~m}$ and $0.50 \mathrm{~m}$. The experimental design consisted of completely randomized blocks with four replications and five irrigation regimes. The experimental area was used for both years and divided into four blocks with five elementary plots per block. Each elementary plot consisted of eight rows. All plots were drip irrigated with water from a well having an $\mathrm{EC}_{i}$ of $3.6 \mathrm{dS} \cdot \mathrm{m}^{-1}$. Each dripper had a $4 \mathrm{l} \cdot \mathrm{h}^{-1}$ flow rate. Water for each block passed through a water meter, gate valve, before passing through laterals placed in every onion row. A control minivalve in the lateral permits use or nonuse of the dripper line. The uniformity of emitter water application was checked by recording the time needed for the discharge to fill a vessel of known volume. The average discharge of the emitters was found to be $4 \mathrm{l} / \mathrm{h}$, and the uniformity coefficient was more than $90 \%$ for all the blocks.

Fertilizers were supplied for the cropping periods in the same amounts; before planting, soil was spread with $9 \mathrm{t} \cdot \mathrm{ha}^{-1}$ of organic manure. Nutrient supply included N, P, and K at rates of 200, 200 and $200 \mathrm{~kg} \cdot \mathrm{ha}^{-1}$, respectively, which were adopted from the local practices. The $\mathrm{P}$ and $\mathrm{K}$ fertilizers were applied as basal dose before planting. Nitrogen was divided and delivered with the irrigation water in all treatments during early vegetative growth.

Five distinct water treatments were applied: SWB-100 treatment irrigated when readily available water in the root zone has been depleted and plants in that treatment received $100 \%$ of accumulated crop evapotranspiration (full irrigation treatment); two additional treatments were irrigated at the same frequency as treatment SWB-100, but with quantities equal to 60 and $80 \%$ of accumulated $\mathrm{ET}_{c}$ (DI-60 and DI-80, continuously deficit irrigation). These treatments were identified as continuous deficit irrigation treatments. In the fourth treatment (SWB100-MDI60), water was applied from transplanting to the midseason stage, to supply fully the $\mathrm{ET}_{c}$ (regulated deficit irrigation). After that stage, only $60 \%$ of $\mathrm{ET}_{c}$ was applied till harvest. A fifth irrigation treatment consisted of applying the producer method corresponding to irrigation practices traditionally implemented by the local farmers, that is, a fixed amount of water is supplied to the crop every 5 days from transplanting till harvest.

The crop evapotranspiration $\left(\mathrm{ET}_{c}\right)$ was estimated for daily time step by using reference evapotranspiration $\left(\mathrm{ET}_{o}\right)$ combined with onion crop coefficient $\left(K_{c}\right)$. The $\mathrm{ET}_{o}$ was estimated from daily climatic data collected from the institute meteorological station (data not presented) by means of the FAO-56 Penman-Monteith method given in Allen et al. [24]. The onion crop coefficient $\left(K_{c}\right)$ was computed following the recently developed FAO-56 dual crop coefficient approach, the sum soil evaporation $\left(K_{e}\right)$, and basal crop coefficient $\left(K_{c b}\right)$ reduced by any occurrence of soil water stress $\left(K_{s}\right)$, which provides for separate calculations for transpiration and soil evaporation $\left(K_{c}=K_{s} K_{c b}+K_{e}\right)$. 
For irrigation scheduling, the method used was the water balance, by means of a spreadsheet program for Excel, developed according to the methodology formulated by Allen et al. [24]. The spreadsheet program estimates the day when the target soil water depletion (readily available water, RAW) for the treatment SWB-100 would be reached and the amount of irrigation water needed to replenish the soil profile to field capacity. The program calculates the soil water depletion on daily basis using the soil water balance and projects the next irrigation event based on the target depletion ( $30 \%$ of total available water in the root zone, $60 \%$ of TAW). The soil depth of the effective root zone is increased with the program from a minimum depth of $0.15 \mathrm{~m}$ at planting to a maximum of $0.60 \mathrm{~m}$ in direct proportion to the increase in the onion crop coefficient.

2.3. Measurements and Water Use Efficiency. Matured crop was harvested after 145-150 days of transplanting for both years to estimate the onion yield. Fifteen plants per row within each plot were harvested by hand to determine fresh bulbs yield, bulbs number, and bulb weight. Also, fresh bulbs were cut into small pieces and dried at $70^{\circ} \mathrm{C}$ to a constant weight for estimation of dry matter.

Water use efficiency (WUE) is defined as the yield obtained per unit of water consumed, whether from irrigation or total received, therefore including the precipitation. The WUE was calculated as follows: WUE $\left(\mathrm{kg} \cdot \mathrm{ha}^{-1} \cdot \mathrm{mm}^{-1}\right)$ $=$ Yield $\left(\mathrm{kg} \cdot \mathrm{ha}^{-1}\right) /$ total water received $(\mathrm{mm})$ from planting to harvest; an irrigation of $75 \mathrm{~mm}$ applied before planting is not included in the total.

Soil samples were collected after harvest. The soil was sampled with a $4 \mathrm{~cm}$ auger every $15 \mathrm{~cm}$ to a depth of $60 \mathrm{~cm}$. Samples were air-dried and ground to pass a mesh of $2 \mathrm{~mm}$ size and were analyzed for $\mathrm{EC}_{e}$.

2.4. Statistical Analysis. Analysis of variance was performed to evaluate the statistical effect of irrigation treatments on onion yields and components, WUE, and soil salinity using the STATGRAPHICS Plus 5.1 (http://www.statgraphics.com/). LSD test at 5\% level was used to find any significant difference between treatment means.

\section{Results and Discussion}

3.1. Evapotranspiration Estimates and Soil Water Balance. Figure 1 shows computed $K_{c}\left(K_{s} K_{c b}+K_{e}\right)$ during the cropping period in 2008 and 2009. The potential $K_{c}$ values were found to have occurred following rain or irrigation events when the soil surface layer was wetted. The $K_{e}$ spikes represent increased evaporation when irrigation or precipitation has wetted the soil surface and has temporarily increased $\mathrm{ET}_{c}$ values (Figure 2). During the initial stage, the $K_{e}$ spikes reach values of $0.88-0.93$ following wetting by rainfall. Some of the evaporation spikes were lower during this period since only fraction of the soil surface ( $\mathrm{fw}=0.3$ ) was wetted only by irrigation. The wet soil evaporation spikes decrease as the soil surface layer dries and the value of $K_{e}$ became zero during the growing period when the soil surface was dried.

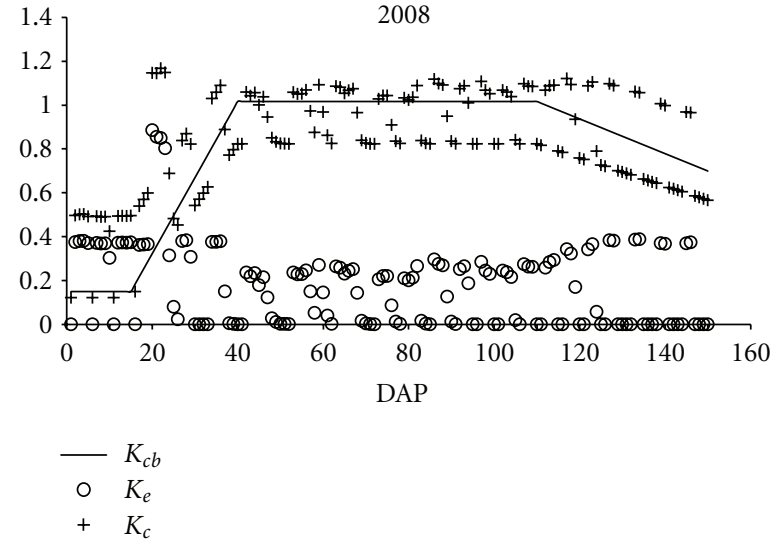

(a)

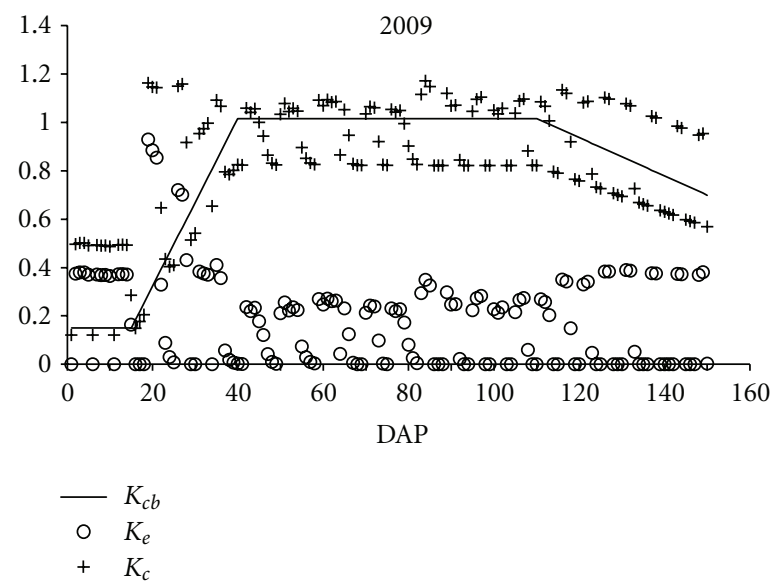

(b)

FIGURE 1: FAO 56 crop coefficient curves for onion crop during the cropping season.

Figure 2 illustrates the course of daily $\mathrm{ET}_{c}$ relative to $\mathrm{ET}_{o}$ for onion crop. During the first 15 days after plantation, high $\mathrm{ET}_{c}$ values were observed because of the important soil evaporation values. Most of the daily crop ET consisted of soil evaporation and controlled mainly by soil hydraulic properties and solar radiation. This period is characterized by mean values of daily $\mathrm{ET}_{c}$ of about 1.3 and $1.24 \mathrm{~mm}$, respectively, for the first and second year. As the crop canopy grew, $\mathrm{ET}_{c}$ increased and reached its highest mean value at midseason stage $\left(3.77\right.$ and $\left.3.74 \mathrm{~mm} \cdot \mathrm{day}^{-1}\right)$. The mean $\mathrm{ET}_{c}$ values at the late stage were about 4.42 and $4.65 \mathrm{~mm}$ day $^{-1}$, respectively, for 2008 and 2009. At the late stage, where the canopy senescence began, the high $\mathrm{ET}_{c}$ values were principally attributed to the important soil evaporation induced by the frequency of irrigation and to the high evaporative demand.

Soil Water Balance. Figure 3 illustrates soil water depletion (SWD), estimated by the spreadsheet program, under SWB100 treatment during the cropping period for the first and second year. The spreadsheet program develops a water balance and supplies information on the timing and amounts 


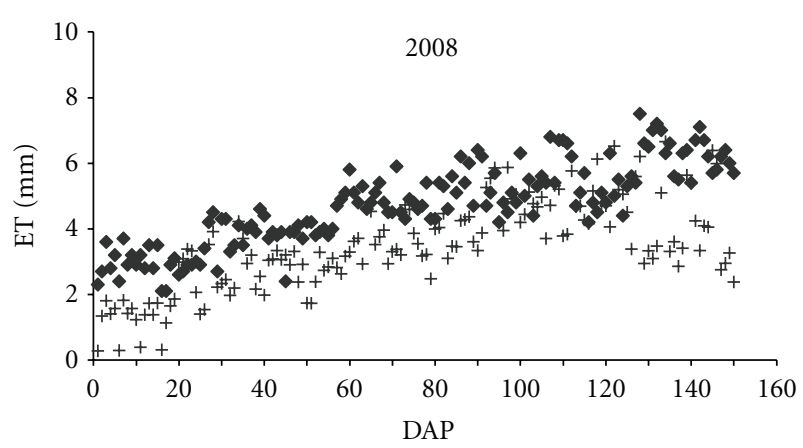

- $\mathrm{ET}_{o}$

$+\mathrm{ET}_{c}$

(a)

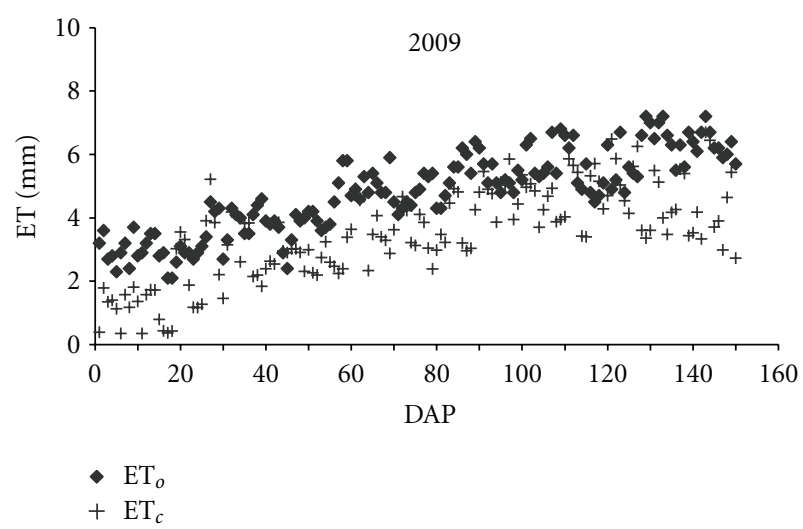

(b)

FIGURE 2: Estimated daily $\mathrm{ET}_{c}$ for onion crop during the cropping season.

of irrigation events. This figure illustrates also the effect of an increasing root zone on the readily available water. The rate of root zone depletion at a particular moment in the season is given by the net irrigation requirement for that period. Each time the irrigation water is applied, the root zone is replenished to field capacity. Because irrigation is not applied in the spreadsheet until the soil water depletion at the end of the previous day is greater than or equal to the readily available water, occasionally plants could be subject to a slight stress on the day prior to irrigation.

3.2. Soil Salinity. The final average $\mathrm{EC}_{e}$ values $(0-60 \mathrm{~cm}$ soil depth) under the different irrigation treatments are presented in Figure 4. Initial soil salinity determined at the time of planting was 2.6 and $2.3 \mathrm{dS} \cdot \mathrm{m}^{-1}$, respectively, for 2008 and 2009. After the crop harvest, $\mathrm{EC}_{e}$ increased under all irrigation treatments in both years. However, the highest $\mathrm{EC}_{e}$ values were found to have occurred when farmer method was used. Values of 6.4 and $6.1 \mathrm{dS} / \mathrm{m}$ were recorded, respectively, in the first and second year. The reason for the higher soil salinity obtained under farmer method may be attributed to the fact that more irrigation water under conditions of high evaporative demand would result in higher direct

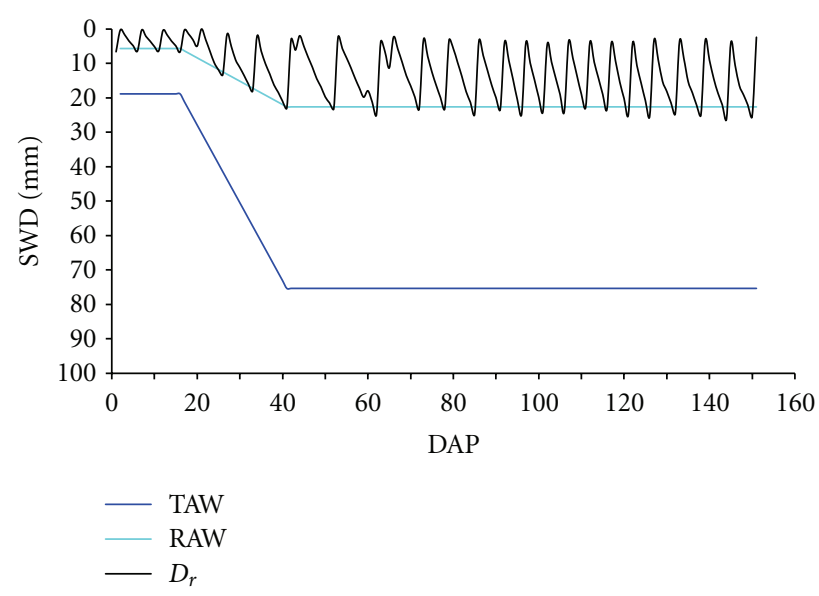

(a)

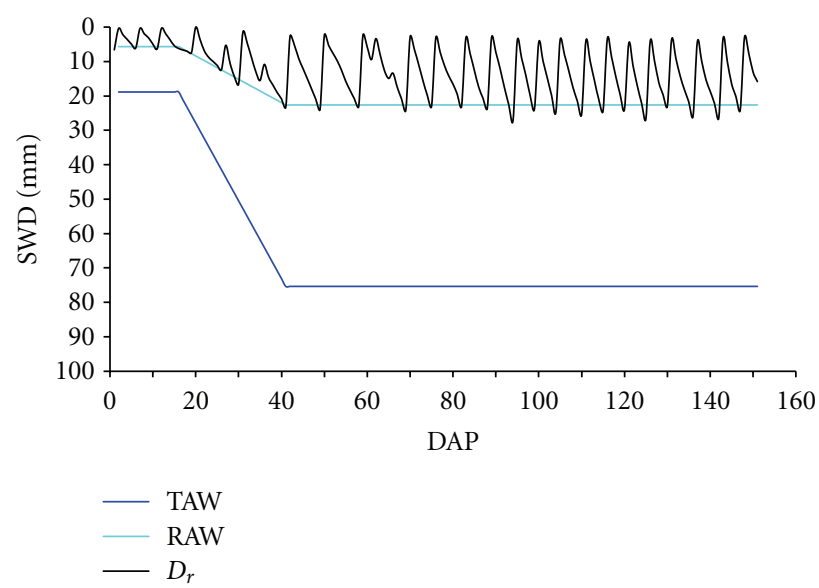

(b)

FIGURE 3: Estimated daily soil water depletion (SWD) for onion under SWB-100 irrigation treatment during the cropping season (a) 2008 and (b) 2009.

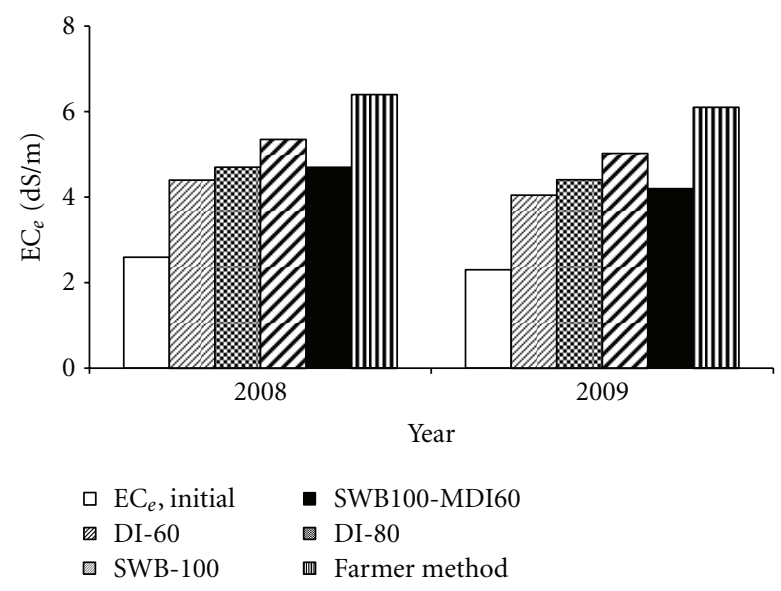

FIGURE 4: Soil salinity $\left(\mathrm{EC}_{e}, \mathrm{dS} / \mathrm{m}\right)$ under the different irrigation treatments. 
TABLE 1: Yield of onion under different irrigation treatments.

\begin{tabular}{|c|c|c|c|c|c|c|}
\hline \multirow{2}{*}{ Treatments } & \multicolumn{3}{|c|}{ Bulbs fresh yield (t/ha) } & \multicolumn{3}{|c|}{ Bulbs dry yield (t/ha) } \\
\hline & 2008 & 2009 & Mean & 2008 & 2009 & Mean \\
\hline SWB-100 & 24.29 & 26.10 & 25.20 & 3.045 & 3.272 & 3.16 \\
\hline DI-80 & 23.17 & 24.98 & 24.08 & 2.905 & 3.132 & 3.02 \\
\hline DI-60 & 22.40 & 23.44 & 22.92 & 2.808 & 2.938 & 2.87 \\
\hline SWB100-MDI60 & 23.50 & 25.64 & 24.57 & 2.946 & 3.214 & 3.08 \\
\hline Farmer method & 18.97 & 21.18 & 20.08 & 2.378 & 2.665 & 2.67 \\
\hline LSD $(5 \%)$ & 1.443 & 2.193 & & 0.311 & 0.280 & \\
\hline
\end{tabular}

TABle 2: Yield components under different irrigation treatments.

\begin{tabular}{|c|c|c|c|c|c|c|}
\hline \multirow{2}{*}{ Treatments } & \multicolumn{3}{|c|}{ Bulbs number (1000/ha) } & \multicolumn{3}{|c|}{ Bulb weight (g) } \\
\hline & 2008 & 2009 & Mean & 2008 & 2009 & Mean \\
\hline SWB-100 & 325.50 & 335.90 & 330.7 & 74.63 & 77.70 & 76.17 \\
\hline DI-80 & 317.70 & 330.80 & 324.3 & 72.93 & 75.50 & 74.22 \\
\hline DI-60 & 314.70 & 317.90 & 316.3 & 71.17 & 73.64 & 72.41 \\
\hline SWB100-MDI60 & 320.90 & 338.30 & 329.6 & 73.22 & 75.79 & 74.51 \\
\hline Farmer method & 288.10 & 299.20 & 293.6 & 68.24 & 70.81 & 69.53 \\
\hline $\operatorname{LSD}(5 \%)$ & 45.142 & 41.510 & & 3.017 & 4.004 & \\
\hline
\end{tabular}

evaporation rates leading to an increase in salt accumulation in the soil.

With SWB irrigation scheduling (SWB-100), the average $\mathrm{EC}_{e}$ value was equal to $4.4 \mathrm{dS} / \mathrm{m}$ in 2008 and to $4.05 \mathrm{dS} / \mathrm{m}$ in 2009. In both years, SWB100-MDI60 and DI-80 irrigation treatments resulted also in low $\mathrm{EC}_{e}$ values. The $\mathrm{EC}_{e}$ values are similar to the $\mathrm{EC}_{e}$ for SWB-100. With DI-60 irrigation treatment, $\mathrm{EC}_{e}$ values increased to 5.35 and $5.02 \mathrm{dS} \cdot \mathrm{m}^{-1}$, respectively, in 2008 and 2009. The higher soil salinity obtained under DI-60 irrigation treatment may be attributed to little leaching of the soil expected under deficit irrigation conditions. Schoups et al. [25] reported that one consequence of reducing irrigation water use by deficit irrigation is the greater risk of increased soil salinity due to reduced leaching.

3.3. Yield and Yield Components. For analyzing the effect of full and deficit irrigation treatments on the final onion yield, four criteria were retained in both years: bulbs fresh yield, bulbs dry yield, bulbs number, and bulb weight. The data concerning the four parameters considered, observed for all irrigation treatments, are presented in Tables 1 and 2.

There were differences between two experiments in onion yields. Yields were highest the second year with all treatments (Table 1) because of the low initial soil salinity. SWB-100 treatment resulted in the maximum bulb fresh yields in 2008 and 2009 (24.29 and 26.10 t/ha). It was found that deficit irrigation at the fourth growth stages (SWB100MDI60) gave nonsignificantly different yield from the full irrigation (SWB-100). Bazza [9], after conducting deficit irrigation experiment for different vegetable crops and for some cereals, concluded that stressing the crops during final stage of the growing season did not affect the crop yield significantly. Although the deficit during the last growth stage (SWB100-MDI60) was only 79 and $69 \mathrm{~mm}$ in the first and second years, the yield reduction was 0.79 and $0.46 \mathrm{t} / \mathrm{ha}$. Studies conducted on irrigation of onion $[12,26-$ 28 ] indicated that the bulbs fresh production of onion are highly dependent on appropriate water supply. Thus, the restrictions of irrigation water during the ripening stage according to our own experience as well as to that of other researchers $[29,30]$ could be implemented without leading to any quantitative or qualitative losses. Yields under the SWB100-MDI60 and SWB-100 treatments were not statistically different from that obtained with DI-80. However, a significant reduction in yields occurred with the DI-60 (Table 1). On the other hand, farmer method decreased significantly the bulb fresh yields (18.97 and $21.18 \mathrm{t} / \mathrm{ha}$ ). In the study area, many farmers withhold irrigation during the last stage and provide inadequate water throughout the growing season. The farmer applies water to the crop regardless of the plant needs, and farmer seems to relate irrigation occurrences to days after planting rather than to crop growth stages progress.

Bulb dry yields increased in SWB-100 and SWB100MDI60 treatments, and a significant decrease in bulb dry yields was observed in deficit irrigation treatment (DI-60) and farmer method (Table 1). The statistical analysis showed significant differences between the treatments except SWB100, SWB100-MDI60, and DI-80. The variation in bulb dry yields might be attributed to variation in weight of bulb (Table 2). Olalla et al. [12] indicated that onion bulb size under drip irrigation system is directly related to amount of water applied.

Bulbs number/ha and weight (Table 2) were influenced by the irrigation treatments although in both years, no significant differences in bulbs number were observed between the five treatments. However, the bulb weight for farmer 
TABLE 3: Water supply ( $\mathrm{mm})$ under different irrigation treatments.

\begin{tabular}{|c|c|c|c|c|}
\hline Treatments & Irrigation $(\mathrm{I})^{*}$ & Irrigation water saved (\%) & Precipitation $(\mathrm{P})$ & $(\mathrm{I}+\mathrm{P})$ \\
\hline \multicolumn{5}{|c|}{2008} \\
\hline SWB-100 & 492 & - & 38 & 530 \\
\hline DI-80 & 394 & 19.9 & 38 & 432 \\
\hline DI-60 & 295 & 40.0 & 38 & 333 \\
\hline SWB100-MDI60 & 413 & 16.1 & 38 & 451 \\
\hline Farmer method & 712 & - & 38 & 750 \\
\hline \multicolumn{5}{|c|}{2009} \\
\hline SWB-100 & 474 & - & 47 & 521 \\
\hline DI-80 & 379 & 20.0 & 47 & 426 \\
\hline DI-60 & 285 & 39.9 & 47 & 332 \\
\hline SWB100-MDI60 & 405 & 14.6 & 47 & 452 \\
\hline Farmer method & 631 & - & 47 & 678 \\
\hline
\end{tabular}

* An irrigation of $75 \mathrm{~mm}$ supplied just before planting is not included in these totals.

TABLE 4: Water use efficiency $\left(\mathrm{kg} \cdot \mathrm{m}^{-3}\right)$ under different irrigation treatments.

\begin{tabular}{|c|c|c|c|c|c|c|}
\hline \multirow{2}{*}{ Treatments } & \multicolumn{3}{|c|}{ IWUE } & \multicolumn{3}{|c|}{ TWUE } \\
\hline & 2008 & 2009 & Mean & 2008 & 2009 & Mean \\
\hline SWB-100 & 4.94 & 5.51 & 5,23 & 4.58 & 5.01 & 4,80 \\
\hline DI-80 & 5.88 & 6.59 & 6,24 & 5.36 & 5.86 & 5,61 \\
\hline DI-60 & 7.59 & 8.23 & 7,91 & 6.73 & 7.06 & 6,90 \\
\hline SWB100-MDI60 & 5.69 & 6.33 & 6,01 & 5.21 & 5.67 & 5,44 \\
\hline Farmer method & 2.66 & 3.36 & 3,01 & 2.53 & 3.12 & 2,83 \\
\hline LSD (5\%) & 0.881 & 0.946 & & 1.175 & 1.179 & \\
\hline
\end{tabular}

method and DI-60 treatment was lowest, while SWB-100, DI-80, and SWB100-MDI60 irrigation treatments did not differ significantly from each other. Onion crop productivity is most sensitive to water stress during bulbification stage $[12,31]$. Chung [31] reported that water stress during critical growth period causes reduction in bulbs number and weight. Note that the deficit irrigation treatment (DI-60) and farmer method result in higher salinity in the rooting zone than the DI-80, SWB-100, and SWB100-MDI60 strategies (Figure 4). The higher salinity associated with deficit irrigation (DI60) and farmer methods were sufficient to cause reduction in onion yield, through a reduction in bulbs number and weight (Table 2). These results obtained under the prevailing climatic conditions support the practicality of the DI-80, SWB-100, and SWB100-MDI60 strategies to facilitate the use of saline water for irrigation of onion.

3.4. Water Use Efficiency. Data on the amounts of applied irrigation water under the different irrigation treatments in both years are presented in Table 3. For all treatments, total water supply ranged from about 332 to $750 \mathrm{~mm}$. The irrigation water applied to SWB-100, DI-80, DI-60, SWB100-MDI60, and farmer method were, respectively, $492,394,295,413$, and $712 \mathrm{~mm}$ for the first year and $474,379,285,405$, and $631 \mathrm{~mm}$ in the second year. The amounts of irrigation water in the two experiments were similar to those reported by Kadayifci et al. [32], Mermoud et al. [33], Kumar et al. [22], and Bekele and Tilahun [21]. Among the irrigation treatments tested, the irrigation water supply was the highest under farmer method in both years. The full irrigation (SWB-100) received 45 and 33.1\% less irrigation water than the farmer method, respectively, in 2008 and 2009 (Table 3). Therefore, irrigation water applied to farmer method was considered in excess of actual irrigation water requirement. We thus used full irrigation treatment (SWB-100), not the farmer method, as the basis for comparison of irrigation treatments in saving water. As expected, the deficit irrigation treatments required less water than the full-irrigated treatment (SWB-100). The net saving in irrigation water with DI-80, DI-60, and SWB100-MDI60 were, respectively, 19.9, 40, and $16.1 \%$ for the first year and $20,39.9$, and $14.6 \%$ in the second year when compared with full irrigation treatment (SWB-100).

Water use efficiency (WUE) is defined as the relationship between units produced and volume of irrigation water applied [34]. Table 4 shows the WUE value in our experiment expressed as kilograms of fresh bulb weight produced per cubic meter of irrigation and total water received from planting to harvest. The WUEs values obtained for the first and second year experiments are comparable with those obtained in other field studies $[21,22,32]$ and were affected by irrigation treatments.

For both experiments, the WUE with SWB-100 treatment was not significantly different from those obtained with 
DI-80 and SWB100-MDI60 treatments but statistically different from that obtained with DI-60 and farmer treatments. The difference was also significant between DI- 80 treatment and the DI-60 and farmer treatments. These last two show a statistical difference between them.

The lowest IWUE was achieved under the farmer irrigation method where the grower used no quantitative assessment to determine the amount of irrigation water to be applied. The low WUE for the farmer method during the two experiments can be attributed to reduced yields but also to higher irrigation water use. The deficit irrigation treatments with $20 \%$ and $40 \%$ less irrigation water (DI80 , DI-60) gave proportionally higher IWUE compared to other treatments (Table 3). Our results therefore suggest that irrigation water requirements of onion crop can easily be reduced by $42-45 \%$ and $36-40 \%$ of farmer method, respectively, in 2008 and 2009, without significant yield reduction in the Mediterranean arid regions if the SWB100MDI and DI-80 deficit irrigation practices are adopted. This suggests that increasing the irrigated area with the saved water would compensate for any yield loss.

\section{Conclusion}

Results of this study indicate that full irrigation (SWB100) and deficit irrigation (SWB100-MDI60 and DI-80) treatments decreased the soil salinity. Higher soil salinity was maintained in the root zone with DI-60 deficit irrigation strategy and farmer method. Onion yields were influenced by irrigation treatments. Bulb fresh yields of deficit-irrigated treatment (DI-60) and farmer method were significantly lower than those in full irrigation treatment (SWB-100). Treatments SWB100-MDI60 and DI-80 give also good yields. Deficit-irrigation treatment DI-60 resulted in lower yields and in higher salinity in the root zone than full irrigation (SWB-100) and SWB100-MDI60 and DI-80 treatments. The "fixed amount approach" used by the farmer gave the lowest bulb fresh yields, that is, 22-19\% less than SWB-100 with 45 and $33 \%$ more water and resulted in higher salinity in the rooting zone.

The water use efficiency (WUE) for onion yield was significantly affected by irrigation treatments. The lowest values occurred under the farmer method, while the highest values were obtained under DI-60 deficit-irrigation treatment. Although high efficiencies were observed for the most severe restriction (DI-60), the yield and quality obtained under this treatment do not allow opting for such important reduction. The relatively high yields and water use efficiency values noted under DI-80 and SWB100-MDI60 treatments indicate the high potential of the onion crop to valorize irrigation waters of limited quality under mild continuous and regulated deficit-irrigation.

Based on results, obtained under actual farming conditions, it can be concluded that the full irrigation (SWB100 ) and continuous and regulated deficit-irrigation (DI-80 and SWB100-MDI60) strategies offer significant advantage for both onion yields and WUE and reduce the buildup of salinity compared to the DI-60 and farmer irrigation practices in onion production under arid conditions.
As a result of this research, full irrigation based on SWB method (SWB-100) is recommended for irrigation of onion crop under the arid climate of southern Tunisia. In case of situations where water supply is limited, irrigation of onion could be scheduled using DI-80 and SWB100-MDI60 continuously and regulated deficit-irrigation strategies.

\section{References}

[1] M. English and B. Nakamura, "Effects of deficit irrigation and irrigation frequency on wheat yields," Journal of Irrigation and Drainage Engineering, vol. 115, no. 2, pp. 172-184, 1989.

[2] M. English and S. N. Raja, "Perspectives on deficit irrigation," Agricultural Water Management, vol. 32, no. 1, pp. 1-14, 1996.

[3] F. T. Mugabe and E. Z. Nyakatawa, "Effect of deficit irrigation on wheat and opportunities of growing wheat on residual soil moisture in Southeast Zimbabwe," Agricultural Water Management, vol. 46, no. 2, pp. 111-119, 2000.

[4] G. Ghinassi and P. Trucchi, "Deficit irrigation trials on maize in an Mediterranean semi-arid environment," International Water and Irrigation, vol. 21, no. 1, pp. 12-17, 2001.

[5] C. R. Kirda, "Deficit irrigation scheduling based on plant growth stages showing water stress tolerance," Deficit Irrigation Practices, FAO Water Reports, vol. 22, pp. 3-10, 2002.

[6] X. Mao, M. Liu, X. Wang, C. Liu, Z. Hou, and J. Shi, "Effects of deficit irrigation on yield and water use of greenhouse grown cucumber in the North China Plain," Agricultural Water Management, vol. 61, no. 3, pp. 219-228, 2003.

[7] R. K. Panda, S. K. Behera, and P. S. Kashyap, "Effective management of irrigation water for wheat under stressed conditions," Agricultural Water Management, vol. 63, no. 1, pp. 37-56, 2003.

[8] Y. Zhang, E. Kendy, Y. Qiang, L. Changming, S. Yanjun, and S. Hongyong, "Effect of soil water deficit on evapotranspiration, crop yield, and water use efficiency in the North China Plain," Agricultural Water Management, vol. 64, no. 2, pp. 107-122, 2004.

[9] M. Bazza, "Improving irrigation management practices with water-deficit irrigation," in Crop Yield Response to Deficit Irrigation, Developments in Plant and Soil Sciences, C. Kirda, P. Moutonner, C. Hera, and D. R. Nielsen, Eds., vol. 84, pp. 49-71, Kluwer Academic, Dodrecht, The Netherlands, 1999.

[10] H. Kirnak, I. Tas, C. Kaya, and D. Higgs, "Effects of deficit irrigation on growth, yield, and fruit quality of eggplant under semi-arid conditions," Australian Journal of Agricultural Research, vol. 53, no. 12, pp. 1367-1373, 2002.

[11] M. H. Ali, M. R. Hoque, A. A. Hassan, and A. Khair, "Effects of deficit irrigation on yield, water productivity, and economic returns of wheat," Agricultural Water Management, vol. 92, no. 3, pp. 151-161, 2007.

[12] F. J. Olalla, A. Domínguez-Padilla, and R. López, "Production and quality of the onion crop (Allium cepa L.) cultivated under controlled deficit irrigation conditions in a semi-arid climate," Agricultural Water Management, vol. 68, no. 1, pp. 77-89, 2004.

[13] F. J. Olalla, J. A. de Juan, and C. Fabeiro, "Growth and production of onion crop (Allium cepa L.) under different irrigation schedulings," European Journal of Agronomy, vol. 3, no. 1, pp. 85-92, 1994.

[14] F. J. Olalla, J. A. de Juan, and C. Fabeiro, "Growth and yield analysis of soybean (Glycine Max Merr.) under different irrigation schedules in Castilla-La Mancha," European Journal of Agronomy, vol. 3, no. 3, pp. 187-196, 1994. 
[15] M. Bazza and M. Tayaa, "Contribution to improve sugar beet deficit irrigation," in Crop Yield Response to Deficit Irrigation, Developments in Plant and Soil Sciences, C. Kirda, P. Moutonner, C. Hera, and D. R. Nielsen, Eds., vol. 84, pp. 72-97, Kluwer Academic, Dodrecht, The Netherlands, 1999.

[16] C. Fabeiro, F. J. Olalla, and J. A. de Juan, "Yield and size of deficit irrigated potatoes," Agricultural Water Management, vol. 48, no. 3, pp. 255-266, 2001.

[17] C. Fabeiro Cortés, F. J. Olalla, and J. A. de Juan, "Production of muskmelon (Cucumis melo L.) under controlled deficit irrigation in a semi-arid climate," Agricultural Water Management, vol. 54, no. 2, pp. 93-105, 2002.

[18] C. Fabeiro Cortés, F. J. Olalla, and R. López Urrea, "Production of garlic (Allium sativum L.) under controlled deficit irrigation in a semi-arid climate," Agricultural Water Management, vol. 59, no. 2, pp. 155-167, 2003.

[19] C. Fabeiro Cortés, F. J. Olalla, R. López Urrea, and A. Domínguez, "Production and quality of the sugar beet (Beta vulgaris L.) cultivated under controlled deficit irrigation conditions in a semi-arid climate," Agricultural Water Management, vol. 62, no. 3, pp. 215-227, 2003.

[20] S. M. Sezen, A. Yazar, A. Akyildiz, H. Y. Dasgan, and B. Gencel, "Yield and quality response of drip irrigated green beans under full and deficit irrigation," Scientia Horticulturae, vol. 117, no. 2, pp. 95-102, 2008.

[21] S. Bekele and K. Tilahun, "Regulated deficit irrigation scheduling of onion in a semiarid region of Ethiopia," Agricultural Water Management, vol. 89, no. 1-2, pp. 148-152, 2007.

[22] S. Kumar, M. Imtiyaz, A. Kumar, and R. Singh, "Response of onion (Allium cepa L.) to different levels of irrigation water," Agricultural Water Management, vol. 89, no. 1-2, pp. 161-166, 2007.

[23] E. V. Maas and G. J. Hoffman, "Crop salt tolerance: current assessment," Journal of the Irrigation and Drainage Division, vol. 103, no. 2, pp. 115-134, 1977.

[24] R. G. Allen, L. S. Perreira, D. Raes, and M. Smith, Crop Evapotranspiration: Guidelines for Computing Crop Water Requirements, FAO Irrigation and Drainage, Rome, Italy, 1998.

[25] G. Schoups, J. W. Hopmans, C. A. Young et al., "Sustainability of irrigated agriculture in the San Joaquin Valley, California," Proceedings of the National Academy of Sciences of the United States of America, vol. 102, no. 43, pp. 15352-15356, 2005.

[26] S. O. Koriem, M. M. A. El-Koliey, and M. F. Wahba, "Onion bulb production from "Shandwell" sets as affected by soil moisture stress," Assuit Journal of Agriculture Science, vol. 25, pp. 185-193, 1994.

[27] C. C. Shoke, E. B. G. Feibert, and L. D. Saunders, "Onion yield and quality affected by soil water potential as irrigation threshold," Horticulture Science, vol. 33, no. 7, pp. 1188-1191, 1998.

[28] C. C. Shoke, E. B. G. Feibert, and L. D. Saunders, "Irrigation criteria for drip-irrigated onions," Horticulture Science, vol. 35, no. 1, pp. 63-66, 2000.

[29] W. R. Jordan, "Whole plants response to water deficit: an overview," in Limitations of Efficient Water Use in Crop Production, H. M. Taylor, W. R. Jordan, and T. R. Sinclair, Eds., pp. 289-317, ASA, CSSA and SSSA, Madison, Wis, USA, 1983.

[30] T. A. Howell, R. H. Cuenca, and K. H. Solomon, "Crop yield response," in Management of Farm Irrigation System, G. J. Hoffman, Ed., vol. 9, pp. 93-122, Monograph, St. Joseph, Mich, USA, 1990.

[31] B. Chung, "Irrigation and bulb onion quality," Acta Horticulturae, vol. 247, pp. 233-236, 1989.
[32] A. Kadayifci, G. I. Tuylu, Y. Ucar, and B. Cakmak, "Crop water use of onion (Allium cepa L.) in Turkey," Agricultural Water Management, vol. 72, no. 1, pp. 59-68, 2005.

[33] A. Mermoud, T. D. Tamini, and H. Yacouba, "Impacts of different irrigation schedules on the water balance components of an onion crop in a semi-arid zone," Agricultural Water Management, vol. 77, no. 1-3, pp. 282-293, 2005.

[34] P. Steduto, "Water use efficiency," in Sustainability of Irrigated Agriculture, L. S. Pereira, R. A. Feddes, J. R. Gilley, and B. Lesaffre, Eds., vol. 312 of NATA ASI Series E: Applied Sciences, Kluwer Academic, London, UK, 1996. 


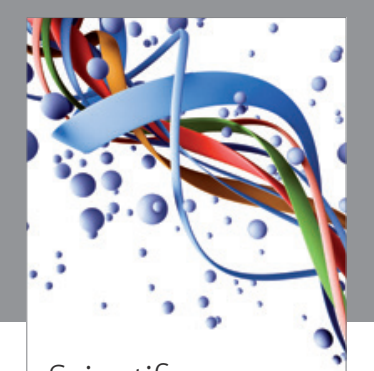

Scientifica
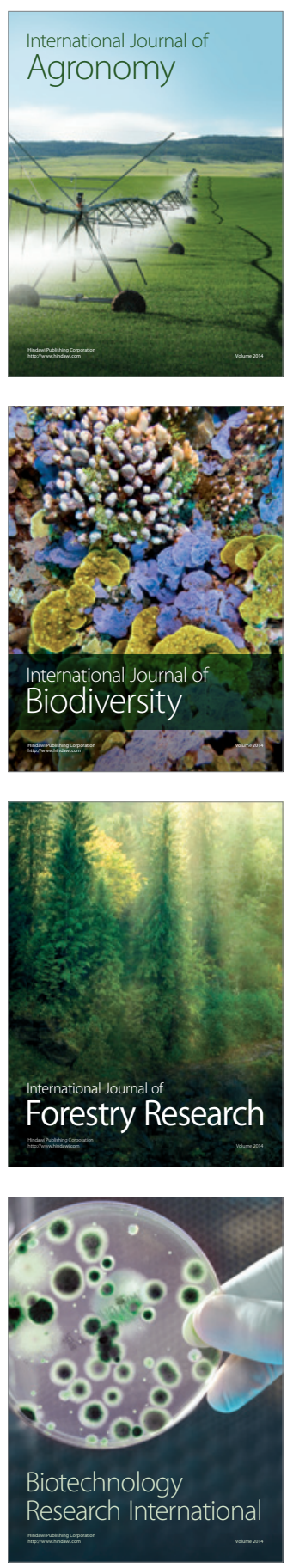
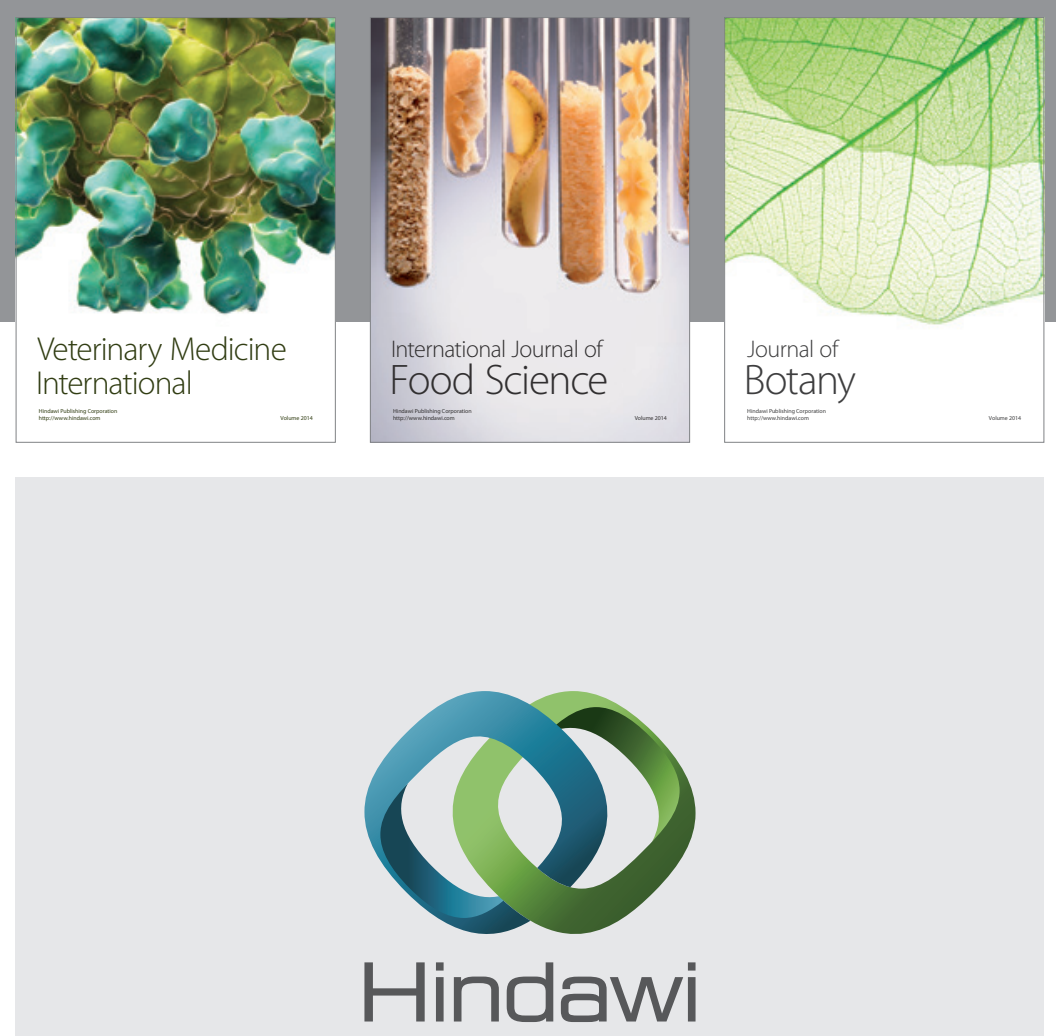

Submit your manuscripts at

http://www.hindawi.com
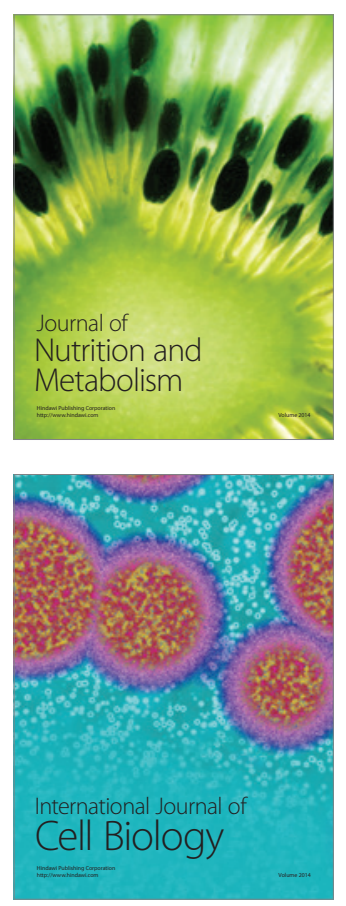
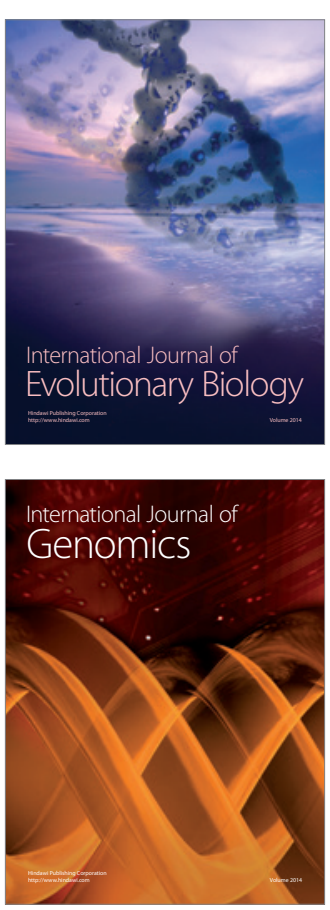
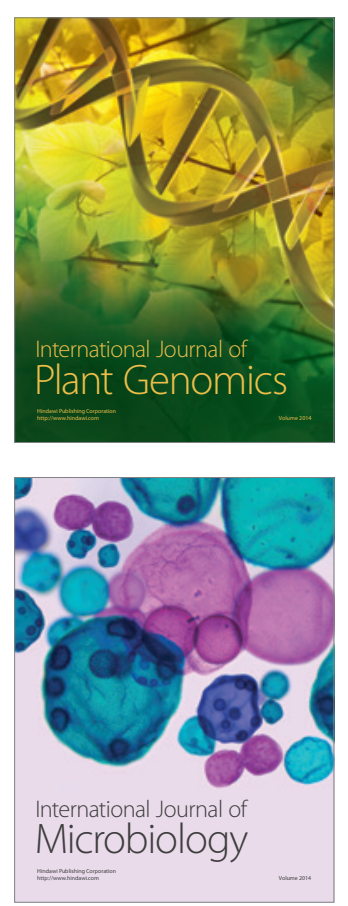

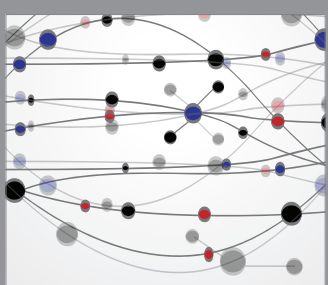

The Scientific World Journal
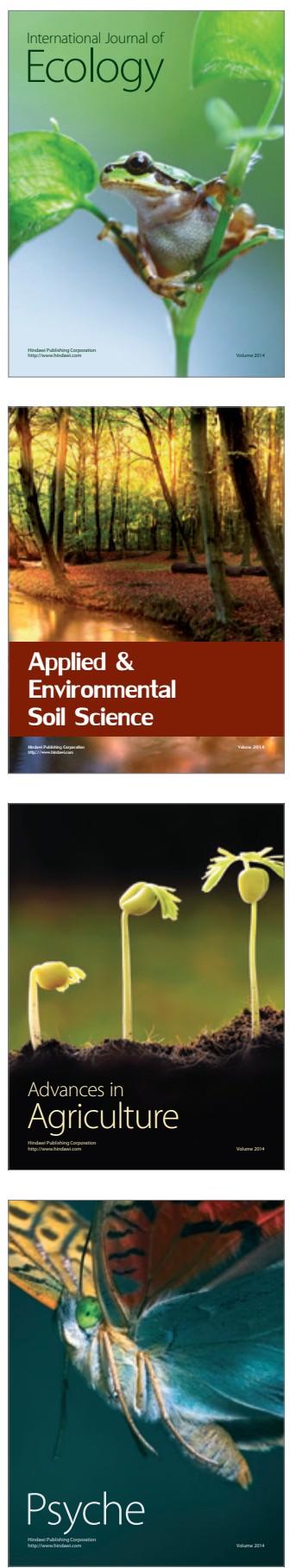